\title{
RANCANG BANGUN SISTEM SORTASI KEMATANGAN BUAH SEMI OTOMATIS BERBASIS ARDUINO
} Design of Sortation Semi Automatic System of Fruits Based On Arduino

\author{
Guyup Mahardhian Dwi Putra ${ }^{1)}$, Diah Ajeng Setiawati ${ }^{1)}$, Sumarjan ${ }^{2)}$ \\ ${ }^{1)}$ Program Studi Teknik Pertanian Fakultas Teknologi Pangan Universitas Mataram \\ Jl. Majapahit 62 Mataram 83125 \\ ${ }^{2)}$ Fakultas Pertanian, Universitas Mataram \\ Jl. Majapahit 62 Mataram 83125 \\ E-mail: guyupmdp@unram.ac.id
}

\begin{abstract}
ABSTRAK
Paprika (Capsicum annuum L.) adalah tumbuhan penghasil buah yang berasa manis dan sedikit pedas. Akhir-akhir ini paprika menjadi tanaman sayuran berpotensi karena semakin banyak masyarakat yang mengkonsumsi paprika sebagai pelengkap bahan masakan. Perubahan pola konsumsi memberikan peluang besar bagi pasar lokal maupun ekspor. Salah satu daerah penghasil paprika adalah Nusa Tenggara Barat, dimana paprika menjadi komoditi andalan bagi hotel dan restoran yang jumlahnya semakin meningkat sehingga kebutuhan juga semakin bertambah. Kualitas paprika untuk hotel dan restoran tentunya harus memenuhi standar yang telah ditetapkan seperti tingkat kematangan buah. Tujuan penelitian ini adalah merancang bangun alat sortasi kematangan buah semi otomatis berbasis arduino. Metode penelitian ini adalah eksperimental dengan menganalis rancangan struktural dan rancangan fungsional dari sistem sortasi. Alat yang digunakan adalah mikrokontroller arduino UNO REV3, sensor warna TCS 3200, LCD 16x2, power supply, motor servo. Sistem sortasi dirancang dengan prinsip mendeteksi nilai Red Green Blue (RGB) buah paprika menggunakan sensor, data nilai selanjutnya diolah oleh mikrokontroller untuk ditampilkan di LCD dan secara bersamaan menggerakkan portal yang terhubung dengan motor servo. Portal bergerak jika buah matang dan sebaliknya tetap tertutup jika buah mentah. Hasil yang diperoleh bahwa alat sortasi semi otomatis mampu memberikan tingkat keberhasilan 93,3\% dalam membedakan buah paprika matang (merah dan kuning) dari buah mentah (hijau).
\end{abstract}

Kata kunci: arduino, paprika, sistem sortasi, tingkat kematangan

\begin{abstract}
Paprika (Capsicum annuum L.) is a plant producing fruit that tastes sweet and less spicy. Lately, paprika has become a potential vegetable crop as more people are consuming peppers as a complementary cooking ingredient. Changes in consumption patterns provide great opportunities for both local and export markets. One of the paprika producing regions is West Nusa Tenggara, where paprika is a leading commodity for the increasing number of hotels and restaurants; therefore, the need of paprika is also increasing. The quality of paprika for hotels and restaurants must surely meet established standards such as fruit maturity level. The purpose of this research is to design and construct Arduino based semi-automatic fruit sorting tool. The method of this research was experimental by analyzing the structural design and the functional design of the sorting system. The tool used was Arduino UNO Rev3 microcontroller, TCS3200 color sensor, 16x2 LCD, power supply, and servo motor. The sorting system was designed with the principle of detecting Red Green Blue (RGB) value of paprika fruit using the sensor, value data then further processed by microcontroller to be displayed on the LCD and simultaneously moving the portal which connected with servo motor. The portal moves if the fruit is ripe but remains closed if the fruit is raw. The obtained results showed that the semi-automatic sorting tool was able to provide $93.3 \%$ success rate in distinguishing ripe paprika (red and yellow) from the raw one (green).
\end{abstract}

Keywords: arduino, paprika, sorting system, level of maturity

Diterima : 20 April 2018 ; Disetujui : 2 Mei 2018; Online Published : -

DOI : 10.24198/jt.vol12n1.6 


\section{PENDAHULUAN}

Paprika (Capsicum annuum L.) adalah tumbuhan penghasil buah yang berasa manis dan sedikit pedas dengan kandungan vitamin $\mathrm{C}$ sangat tinggi. Setiap $100 \mathrm{~g}$ paprika merah mengandung $190 \mathrm{mg}$ vitamin C (Warsi dan Guntarti, 2013). Paprika mengandung gizi yang cukup tinggi, karena pada setiap $100 \mathrm{~g}$ buah hijau segar mengandung protein $0,90 \mathrm{~g}$, lemak 0,30 g, karbohidrat 4,40 g, vitamin A 22,00 IU, vitamin B1 540,00 mg, vitamin C 160,00 mg (Tulung dan Demmasabu, 2011). Akhir-akhir ini paprika menjadi tanaman sayuran berpotensi karena semakin banyak masyarakat yang mengkonsumsi paprika sebagai pelengkap bahan masakan. Perubahan pola konsumsi memberikan peluang besar bagi pasar lokal maupun ekspor. Salah satu daerah penghasil paprika adalah Nusa Tenggara Barat, dimana paprika menjadi komoditi andalan bagi hotel dan restoran yang jumlahnya semakin meningkat sehingga kebutuhan juga semakin bertambah.

Kualitas paprika untuk hotel dan restoran tentunya harus memenuhi standar yang telah ditetapkan sehingga dalam hal ini diperlukan sistem sortasi. Kegiatan sortasi meliputi kegiatan pemilahan fraksi berdasarkan karakteristik fisik (kadar air, bentuk ukuran berat, jenis, tekstur, warna, benda asing/kotoran), kimia (komposisi bahan, bau, dan rasa ketengikan) dan kondisi biologisnya (jenis dan kerusakan oleh serangga, jumlah mikroba, dan daya tumbuh khusus untuk benih). Sortasi secara umum bertujuan menentukan klasifikasi komoditas berdasarkan mutu sejenis yang terdapat dalam komoditas itu sendiri (Anugrahandy, dkk., 2013).

Kualitas paprika ditentukan oleh berbagai parameter diantaranya adalah parameter tingkat kematangan buah berdasarkan warna. Umumnya sortasi dilakukan dengan dua cara, yaitu manual (menggunakan indera manusia) dan mekanis (menggunakan alat atau mesin). Sortasi yang dilakukan secara manual adalah sortasi yang berdasarkan warna dan kerusakan. Sedangkan yang didasarkan pada ukuran dan berat biasanya dilakukan secara mekanis. Sortasi dengan cara manual memiliki beberapa kelemahan diantaranya produk yang disortasi tidak memiliki tingkat keseragaman yang sama dan membutuhkan tenaga kerja yang banyak. Oleh karena itu, untuk mengatasi masalah tersebut dikembangkan alat sortasi yang menggunakan kontrol guna memperoleh hasil produk yang lebih seragam berdasarkan warna.

Sistem pemantauan dan pengendalian berbasis mikrokontroler telah banyak digunakan dalam bidang teknik pertanian (Setiawati, 2017). Salah satu penggunaannya adalah pada tahap pasca panen, dimana mikrokontroler digunakan sebagai komponen utama dalam sistem otomatisasi pada alat sortasi buah. Penelitian mengenai perancangan alat sortasi telah banyak dilakukan, diantaranya oleh Anugrahandy, A., dkk (2013) mengenai alat sortasi buah apel; Soedibyo, dkk. (2012) mengenai alat sortasi kopi beras; Radityo, Dimas R, dkk. (2012) mengenai alat penyortir buah berdasarkan warna. Menurut Arivazhagan, et al. (2010) dan Li, et al. (2009) terdapat beberapa metode yang dapat dilakukan untuk mengetahui kematangan buah, yaitu berdasarkan intensitas, warna, bentuk ataupun tekstur buah.

Adapun tujuan dari penelitian ini adalah merancang sistem sortasi semi otomatis berbasis mikrokontroler Arduino. Alat sortasi yang dirancang dalam penelitian ini menggunakan sensor warna TCS3200 yang bertugas membaca warna Red, Green dan Blue (RGB) yang kemudian dibangkitkan dengan mikrokontroler arduino untuk memisahkan paprika matang dan paprika mentah menggunakan pintu (portal) yang terhubung dengan motor servo.

\section{METODOLOGI}

\section{Waktu dan Tempat}

Penelitian ini dilakukan pada tahun 2017 di Laboratorium Daya dan Mesin Pertanian, Program Studi Teknik Pertanian, Fakultas Teknologi Pangan dan Agroindustri, Universitas Mataram. 


\section{Alat dan Bahan}

Alat: sensor TCS3200, mikrokontroler arduino UNO REV3, motor servo, kabel jumper, LCD 16x2, software citra digital, triplek, dan satu set alat pertukangan.

Bahan: paprika dengan berbagai tingkat kematangan (warna hijau, warna kuning dan warna merah).

\section{Tahapan Penelitian}

Penelitian ini menggunakan 2 (dua) tahap perancangan:

1. Perancangan perangkat lunak (software) pada penelitian ini memanfaatkan aplikasi citra digital (Gambar 1) yang dapat membangkitkan warna Red (merah), Green (hijau) dan Blue (biru) serta tingkat kecerahan Hue, Saturation, Intensity (HSI). Selain itu, dilakukan juga penyusunan bahasa program pada mikrokontroler Arduino UNO Rev 3 yang merupakan tempat pengolahan data dari sensor ke aktuator.

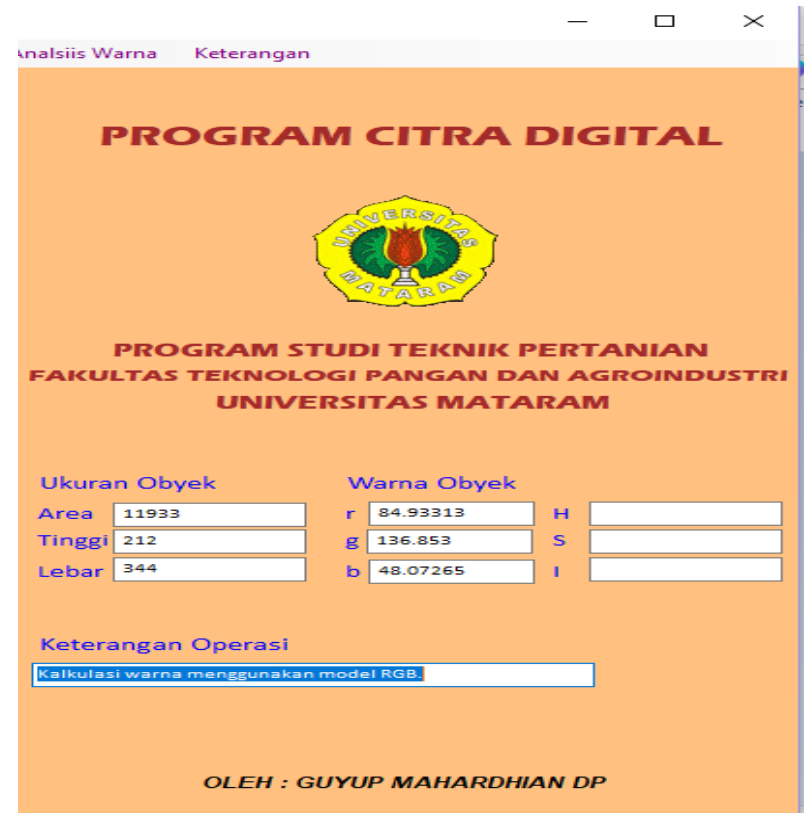

Gambar 1. Tampilan aplikasi citra digital

2. Perancangan mekanik alat dilakukan dengan pendekatan desain struktural dan desain fungsional. Perancangan mekanik alat memberikan pengaruh yang akan menentukan mesin tersebut dapat beroperasi dengan baik.

\section{Perancangan Struktural}

Sensor TCS3200 akan menangkap sinyal berupa nilai RGB yang dijadikan dasar untuk memisahkan paprika matang dan paprika mentah. Sinyal tersebut akan dikirimkan ke mikrokontroler dan akan diolah untuk dapat ditampilkan pada serial monitor dan LCD. Berdasarkan hasil pengolahan data, selanjutnya mikrokontroler akan mengirimkan perintah ke motor servo untuk melakukan sistem sortasi dengan sistem buka tutup pintu (portal) sortasi yang telah didesain seperti pada Gambar 2.

Cara kerja dari alat ini adalah buah diletakkan di atas sensor dengan jarak $2 \mathrm{~cm}$, kemudian nilai RGB akan dibaca untuk dapat menentukan tingkat kematangan paprika. Hasil pembacaan sensor akan ditampilkan di LCD dan hasil pengolahan data akan dikirimkan ke motor servo untuk membuka atau menutup pintu (portal) sortasi. Adanya delay yang telah di-setting akan memberikan waktu yang tepat saat pembukaan dan penutupan pintu sortasi. Alat sortasi dibuat miring dengan tujuan agar paprika dapat meluncur akibat gaya gravitasi setelah didorong dengan tangan.

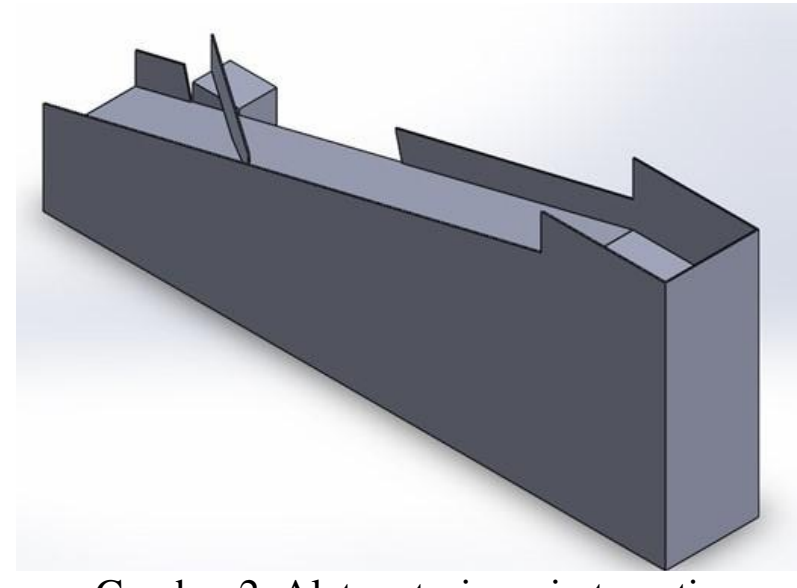

Gambar 2. Alat sortasi semi otomatis

\section{Perancangan Fungsional}

Perancangan fungsional merupakan analisa dari beberapa komponen yang digunakan untuk melaksanakan fungsi sesuai dengan tugasnya yang meliputi: sistem pengumpanan paprika, sistem pengolahan data, sistem buka tutup pintu sortasi, dan sistem output data guna pencatatan. 


\section{Prosedur Penelitian}

Prosedur penelitian ini diperlihatkan pada Gambar 3. Penelitian dimulai dari perancangan mekanik alat sortasi yang terdiri dari hopper, lintasan miring, dan pintu otomatis. Kemudian dirancang perangkat sistem kendali menggunakan mikrokontroler arduino dengan sensor TCS3200 dan motor servo sebagai aktuator. Perancangan terdiri dari pembuatan bahasa program dan pembuatan perangkat lunak citra digital. Setelah itu alat diuji coba apakah sensor mampu membaca nilai RGB dari buah paprika. Jika alat tidak mampu menentukan tingkat kematangan buah berdasarkan RGB dengan tepat, maka dilakukan perbaikan (modifikasi) atau perancangan ulang. Hasil pembacaan warna sensor juga diolah dengan software citra digital untuk menentukan nilai HSI dan RGB sebagai pembanding.

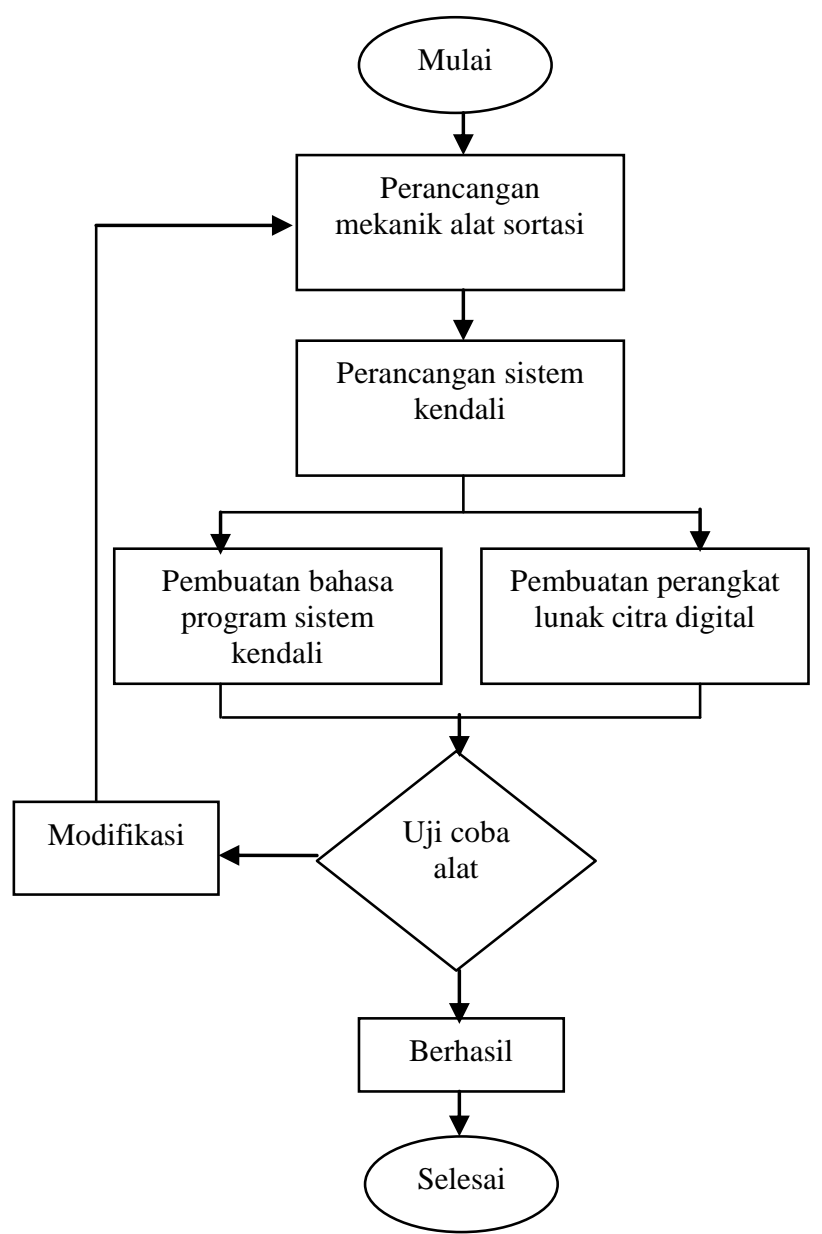

Gambar 3. Diagram alir rancang bangun alat sortasi semi otomatis berbasis Arduino

\section{HASIL DAN PEMBAHASAN}

\section{Perancangan Perangkat Keras}

Perangkat keras pembuatan alat sortasi ini terdiri dari komponen utama berupa sensor warna TCS3200, mikrokontroler arduino UNO REV3, LCD, dan motor servo. Diagram blok penyusunan prangkat keras dapat dilihat pada Gambar 4 berikut.

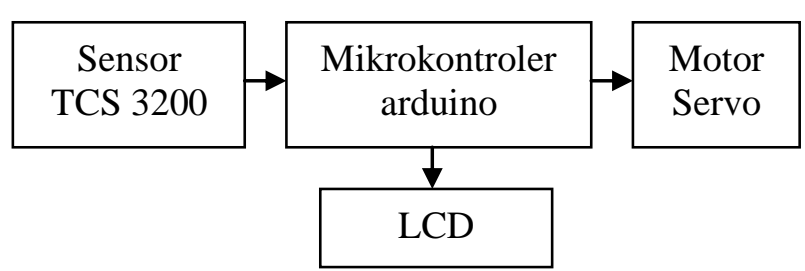

Gambar 4. Diagram blok perancangan perangkat keras

\section{Konfigurasi sensor TCS3200 dengan Arduino UNO REV3}

Sensor warna TCS3200 adalah sensor warna yang sering digunakan pada aplikasi mikrokontroler untuk pendeteksian suatu objek benda atau warna dari objek yang dimonitor (Putra, 2014).

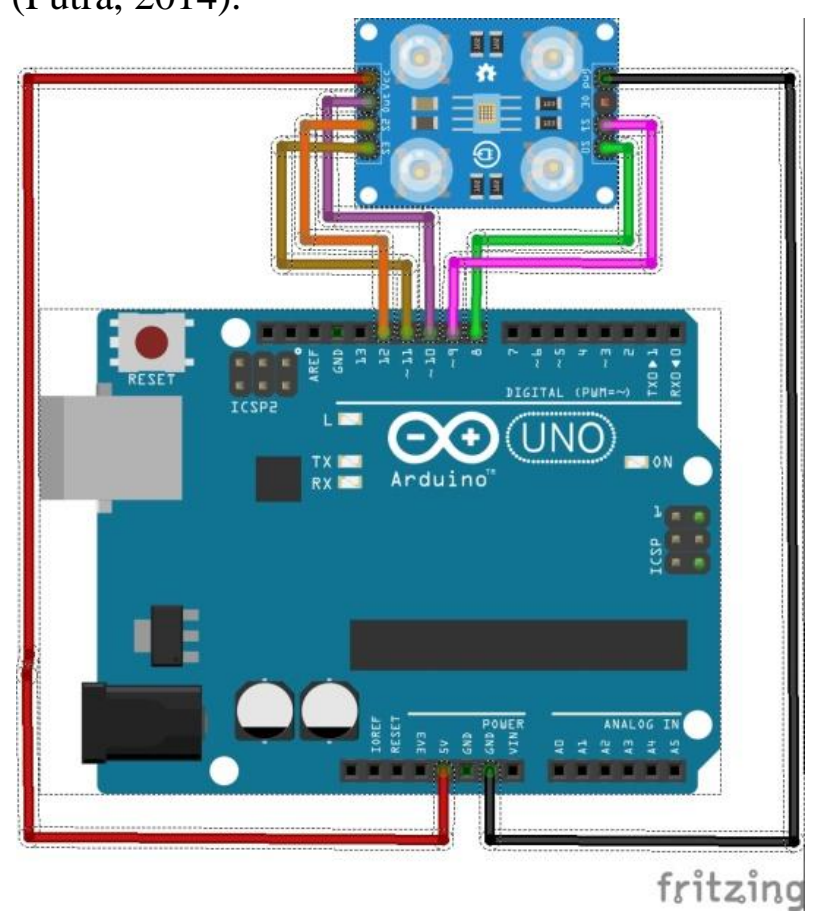

Gambar 5. Blok diagram TCS 3200 dengan Arduino 
IC TCS 3200 dapat dioperasikan dengan supply tegangan pada Vdd berkisar antara 2,7 Volt - 5,5 Volt. Pengoperasian sensor tersebut dapat dilakukan dengan dua cara:

- Dengan mode supply tegangan maksimum, yaitu dengan menyuplai tegangan berkisar antara 2,7 Volt - 5,5 Volt pada sensor warna TCS3200.

- Mode supply tegangan minimum, yaitu dengan menyuplai tegangan 0 sampai 0,8 .

Susunan pin sensor TCS3200 dengan Arduino dapat dilihat pada Tabel 1 berikut.

Tabel 1. Konfigurasi pin TCS3200 dengan pin Arduino

\begin{tabular}{cc}
\hline TCS 3200 & Arduino \\
\hline S0 & D 8 \\
S1 & D 9 \\
OE & Tidak digunakan \\
GND & GND \\
S2 & D 12 \\
S3 & D 11 \\
OUT & D 10 \\
VCC & $5 \mathrm{~V}$ \\
\hline
\end{tabular}

TCS3200 bekerja dengan cara membaca nilai intensitas cahaya yang dipancarkan oleh led super bright terhadap objek. Pembacaan nilai intensitas cahaya tersebut dilakukan melalui matrik $8 \times 8$ photodioda, dimana 64 photodioda tersebut dibagi menjadi 4 kelompok pembaca warna. Setiap warna yang disinari led akan memantulkan sinar led menuju photodioda, pantulan sinar tersebut memiliki panjang gelombang yang berbeda beda tergantung pada warna objek yang terdeteksi. Hal ini yang membuat sensor warna TCS3200 dapat membaca beberapa macam warna.

Tabel 2. Mode pemilihan photodioda pembaca warna

\begin{tabular}{ccc}
\hline S2 & S3 & Photodioda \\
\hline 0 & 0 & Merah \\
0 & 1 & Biru \\
1 & 0 & Clear $($ no filter $)$ \\
1 & 1 & Hijau \\
\hline
\end{tabular}

Panjang gelombang dan sinar led yang dipantulkan objek berwarna berfungsi mengaktifkan salah satu kelompok photodioda pada sensor warna tersebut, sehingga ketika kelompok photodioda yang digunakan telah aktif, S2 dan S3 akan mengirimkan sinyal ke mikrokontroler untuk menginformasikan warna yang dideteksi. Tabel 2 memperlihatkan pemilihan mode pengelompokkan photodioda pembaca warna.

\section{Konfigurasi LCD 16x2 dengan I2C}

Komponen yang digunakan untuk menampilkan data yang telah diolah oleh mikrokontroler Arduino UNO REV3 adalah LCD yang dilengkapi I2C dengan dot matrik 16x2. Perancangan blok LCD dapat dilihat pada Gambar 6.

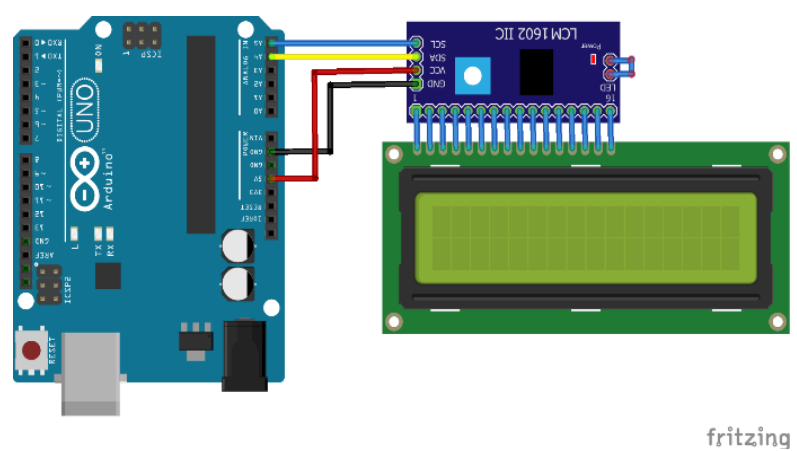

Gambar 6. Blok Diagram Rangkaian LCD (display)

Tabel 3. Konfigurasi pin pada LCD dengan pin pada arduino

\begin{tabular}{lc}
\hline LCD & Arduino \\
\hline GND & GND \\
VCC & $5 \mathrm{~V}$ \\
SDA & A4 \\
SCL & A5 \\
\hline
\end{tabular}

\section{Karaktristik motor servo}

Motor servo merupakan salah satu jenis motor yang memiliki batas putaran maksimal 180 derajat (Pinckney, 2006). Teknik pengendalian motor servo menggunakan PWM (pulse width modulation) dengan memanfaatkan lebar pulsa. Untuk menggerakkan motor servo ke kanan atau kiri tergantung pada delay ketika PWM kondisi high. Misalkan untuk membuat servo pada 
posisi center memberikan delay 1,5 ms pada periode PWM 20 ms (Sujarwata, 2013).

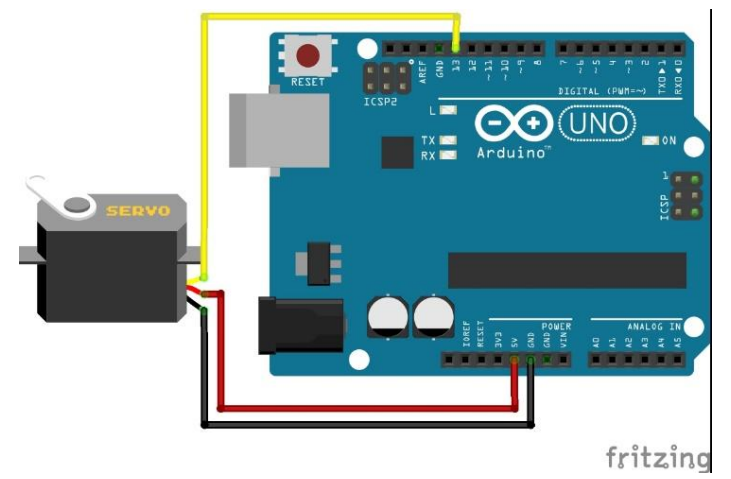

Gambar 7. Blok Diagram rangkaian motor servo

Tabel 4. Konfigurasi pin pada motor servo dengan pin pada Arduino

\begin{tabular}{cc}
\hline Motor Servo & Arduino \\
\hline GND & GND \\
VCC & $5 \mathrm{~V}$ \\
Out & D13 \\
\hline
\end{tabular}

\section{Pengujian alat sortasi}

Mikrokontroler Arduino UNO Rev3 merupakan perangkat elektronik utama yang berfungsi sebagai pengendali agar rangkaian sensor warna, motor servo dan LCD dapat berjalan sesuai fungsinya masing-masing dalam sistem pemantauan yang dirancang.

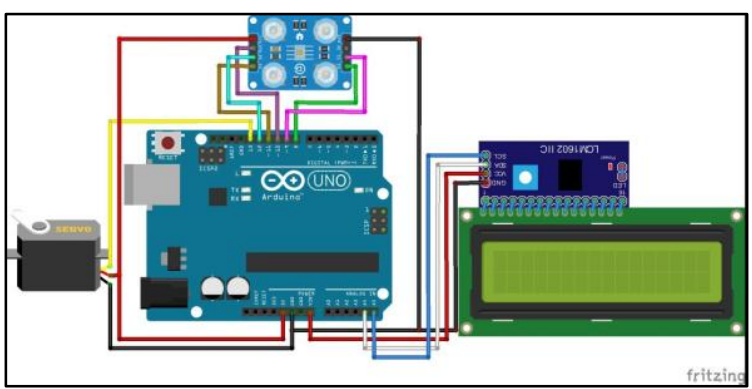

Gambar 8. Rangkaian lengkap sistem sortasi kematangan buah

Sebelum dilakukan pengambilan data, dilakukan proses identifikasi warna merah, hijau dan biru (RGB) paprika mengggunakan perangkat lunak citra digital. Paprika yang dikategorikan matang adalah paprika dengan nilai $\mathrm{R}$ diatas 150 (0-255), nilai $\mathrm{G}$ di bawah 50 (0-255) dan nilai B dibawah 70 (0-255).
Sebaran nilai RGB pada berbagi variasi warna paprika disajikan dalam Tabel 5 berikut.

Tabel 5. Sebaran nilai RGB pada variasi tingkat kematangan paprika

\begin{tabular}{lccc}
\hline \multicolumn{1}{c}{ Buah } & Nilai R & Nilai G & Nilai B \\
\hline Paprika Merah & 176,53 & 35,86 & 66,37 \\
Paprika Kuning & 193,31 & 127,07 & 24,59 \\
Paprika Hijau & 84,95 & 136,85 & 48,07 \\
\hline
\end{tabular}

Seperti yang dapat dilihat pada Tabel 5, paprika yang dikategorikan matang adalah paprika dengan warna merah dan kuning, sedangkan warna hijau dikategorikan paprika mentah. Respon motor servo saat sensor membaca buah matang akan bernilai 1 (high) dan membentuk sudut $45^{\circ}$. Sedangkan saat sensor membaca buah mentah motor servo bernilai 0 (low) dan membentuk sudut $0^{\circ}$. Gambar 9 memperlihatkan pergerakan motor servo sebagai respon terhadap pembacaan sensor.

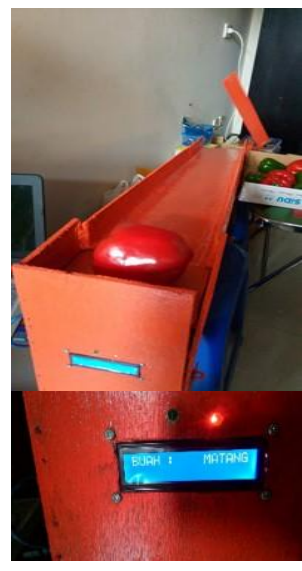

Paprika merah

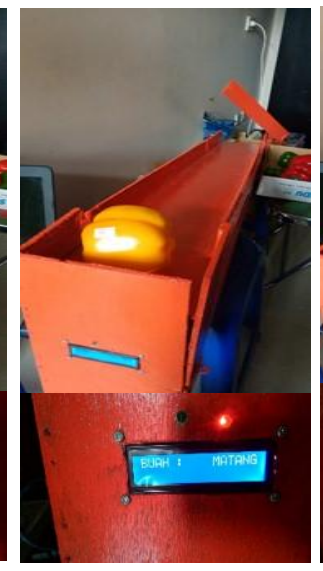

Paprika kuning

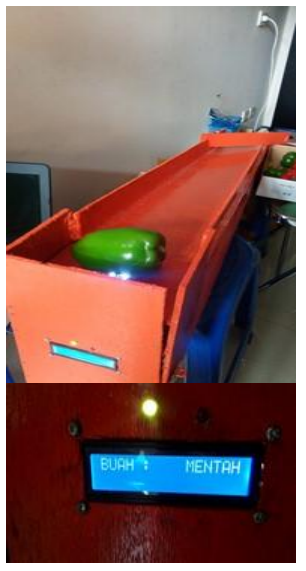

Paprika hijau
Gambar 9. Respon alat sortasi dengan berbagai warna paprika

Sementara itu tingkat keberhasilan alat sortasi dalam membedakan buah paprika yang matang dan mentah dapat dilihat pada Tabel 6 berikut. 
Tabel 6. Tingkat keberhasilan alat sortasi kematangan buah

\begin{tabular}{cccccc}
\hline Jenis & Sampel 1 & Sampel 2 & Sampel 3 & Sampel 4 & Sampel 5 \\
\hline Paprika Merah & berhasil & berhasil & berhasil & berhasil & Berhasil \\
Paprika Kuning & berhasil & berhasil & berhasil & berhasil & Berhasil \\
Paprika Hijau & berhasil & berhasil & gagal & berhasil & berhasil \\
\hline
\end{tabular}

Dari hasil pengujian alat sortasi diperoleh tingkat keberhasilan alat ini dalam membedakan paprika mentah dan matang adalah 93,3\%. Tabel 6 menunjukkan bahwa hasil data yang diperoleh cukup seragam sesuai tingkat kematangan buah, hal ini menunjukkan alat sortasi ini dapat bekerja dengan cukup baik dan cukup akurat dalam melakukan proses penyortiran buah berdasarkan warna. Adapun adanya perbedaan data yang dihasilkan tersebut bisa disebabkan faktor-faktor sebagai berikut:

- Warna paprika yang tidak seragam secara keseluruhan sehingga mengakibatkan kesalahan pembacaan warna pada sensor.

- Adanya pengaruh cahaya yang berbeda maupun kualitas pixel pada kamera sehingga pembacaan nilai RGB bisa berbeda.

\section{KESIMPULAN}

Alat sortasi kematangan buah semi otomatis berbasis mikrokontroler Arduino yang dirancang telah mampu bekerja secara konsisten membedakan paprika matang dan paprika mentah dengan tingkat keberhasilan 93,3\%.

\section{SARAN}

Diperlukan perbaikan mekanisme pengumpanan buah paprika agar dapat bekerja secara otomatis dan diperlukan penambahan sensor agar parameter dalam penentuan sortasi atau grading lebih akurat dan teliti.

\section{DAFTAR PUSTAKA}

Anugrahandy, A., Argo, B.D., Susilo, B. 2013. Perancangan Alat Sortasi Otomatis Buah Apel Manalagi (Malus sylvestris Mill) menggunakan Mikrokontroler AVR
ATMega 16. Jurnal Keteknikan Pertanian Tropis dan Biosistem Vol. 1 No. 1 Februari 2013: 1-9.

Arivazhagan, S., Shebiah, R. N., Nidhyanandhan, S. S., Ganesan, L. 2010. Fruit Recognition using Color and Texture Features. Journal of Emerging Trends in Computing and Information Sciences Vol. 1 No. 2: 90-94.

Li, C., Cao, Q., dan Guo, F. 2009. A Method for Color Classification of Fruits based on Machine Vision. WSEAS Transactions on Systems Vol. 8 No. 2. Shanghai: Shanghai Jiao Tong University.

Putra, Palensyah Pratama. 2014. Aplikasi Sensor Warna TCS3200 pada Sistem Kendali Robot Line Follower. Thesis, Politeknik Negeri Sriwijaya.

Pinckney, N. 2006. Pulse-Width Modulation for Microcontroller Servo Control. IEEE: 27-29.

Radityo, D. R., Fadillah, M. R., Igwahyudi, Q., Dewanto, S. 2012. Alat Penyortir dan Pengecekan Kematangan Buah Menggunakan Sensor Warna. Jurnal Teknik Komputer Vol. 20 No. 2 Agustus 2012: 88-92.

Setiawati, D.A., Putra, G.M.D., Sugandi, W.K. 2017. Uji Kinerja Sistem Pemantauan Volume Biogas berbasis Mikrokontroler Arduino pada Biodigester Tipe Floating Drum. Jurnal Ilmiah Pertanian dan Biosistem Vol .5 No. 2 September 2017: 429-439.

Soedibyo, D. W., Ahmad, U., Seminar, K. B., Subrata, I Dewa Made. 2012. Pengembangan Sistem Pemutuan berbasis Pengolahan Citra dan Jaringan Syaraf Tiruan untuk Alat Sortasi Kopi Beras Tipe Konveyor Sabuk. Disertasi Fakultas Teknologi Pertanian, IPB. 
Sujarwata. 2013. Pengendali Motor Servo Berbasis Mikrokontroler Basic Stamp 2SX untuk Mengembangkan Sistem Robotika. Angkasa Vol. 5 No. 1: 47-54.

Tulung, S. M. T., dan Demmassabu, S. 2011. Pertumbuhan dan Hasil Paprika (Capsicum annuum vargrossum) pada
Beberapa Jenis Naungan. Jurnal Eugenia Vol. 17 No. 2 Agustus 2011: 156-162.

Warsi dan Guntarti, A. 2013. Aktivitas Antioksidan Ekstrak Metanol Buah Paprika Hijau (Capsicum annum L.). Jurnal Ilmiah Kefarmasian, Vol. 3 No. 1: $9-19$ 